\title{
Importance of serum calcium in spontaneous neck haematoma
}

\author{
Matthew Zammit, Richard Siau, Alessandro Panarese
}

ENT, Royal Liverpool and Broadgreen Hospitals NHS Trust, Liverpool, UK

\section{Correspondence to}

Matthew Zammit:

matthewzammit17@gmail.com

Accepted 29 July 2020

Check for updates

(C) BMJ Publishing Group Limited 2020. No commercial re-use. See rights and permissions. Published by BMJ.

To cite: Zammit M, Siau $\mathrm{R}$ Panarese A. BMJ Case Rep 2020;13:e237267. doi:10.1136/bcr-2020237267

\section{SUMMARY}

We present an unusual case of spontaneous cervical haemorrhage secondary to extra-capsular bleeding from a parathyroid adenoma. Signs and symptoms on presentation included sore throat, dysphagia and anterior chest ecchymosis. While CT confirmed active cervical haemorrhage, elevated serum calcium and parathyroid hormone raised suspicion of possible parathyroid pathology. This case report and literature review highlight the diagnostic value of serum calcium in presentations of acute spontaneous neck haematoma. This should be considered especially in the acute phase, where imaging may not identify the source of haemorrhage. Initial observation and deferred surgery is the treatment of choice, with emergency operative management reserved for respiratory distress and worsening compressive symptoms.

\section{BACKGROUND}

Primary hyperparathyroidism (PHPT) is becoming increasingly common due to a rise in biochemical screening for hypercalcaemia. The prevalence of PHPT is estimated to be $1: 1000$, with solitary parathyroid adenomas contributing to $85 \%$ of cases of PHPT. $^{1}$

Infrequently, spontaneous extra-capsular bleeding from parathyroid adenomas may instigate retropharyngeal haemorrhage. This was first reported by Capps, with a parathyroid adenoma being the culprit for a fatal cervical bleed. ${ }^{2}$ However, international guidelines for PHPT fail to discuss the symptomatology and management of this lethal complication. $^{3}$

This case describes the unprompted rupture of a parathyroid adenoma, highlighting the diagnostic importance of serum calcium in spontaneous mediastinal haemorrhage. Its management is further discussed through a review of 39 confirmed cases between 2001 and 2020 (cases with histological/ radiological confirmation that haemorrhage is of a parathyroid origin), summarised in table 1 .

\section{CASE PRESENTATION}

A 65-year-old woman presented to the emergency department with a 4-day history of a painful right anterior neck swelling, hoarse voice, dysphagia and anterior chest ecchymosis. She was seen by her general practitioner a few days prior with clarithromycin prescribed for suspected tonsillitis. She denied any recent trauma. Her medical history consisted of hypothyroidism, taking levothyroxine and was not on any anticoagulants or antiplatelets.

\section{INVESTIGATIONS}

A contrast-enhanced CT scan of the neck and thorax revealed active haemorrhage with a haematoma in superior mediastinum confined to the retropharyngeal space (figures 1 and 2). Bilateral haemathoraces measuring up to $22 \mathrm{~mm}$ axially were also reported. This prompted an immediate patient transfer to a district general hospital with a cardiothoracic and otolaryngology unit.

On arrival, oxygen saturations were $97 \%$ on room air, with a heart rate of 91 beats/min and blood pressure of $158 / 86 \mathrm{~mm} \mathrm{Hg}$. Examination of the oropharynx revealed bruising of the right tonsil and soft palate. Flexible nasendoscopy (FNE) showed submucosal blood in the nasopharynx, hypopharynx and a haematoma within the right aryepiglottic fold, obscuring the right laryngeal inlet. While unable to fully visualise the right vocal cord (VC), full movement of the left VC was confirmed.

Blood investigations showed unremarkable inflammatory markers, liver function tests and clotting screen, with a haemoglobin of $112 \mathrm{~g} / \mathrm{L}$ (baseline $130 \mathrm{~g} / \mathrm{L}$ measured 6 months previously). A serum-corrected calcium $\left(\mathrm{Ca}^{2+}\right)$ of $2.77 \mathrm{mmol} / \mathrm{L}$ (normal range $2.20-2.60 \mathrm{mmol} / \mathrm{L}$ ) and a parathyroid hormone (PTH) level of $12.3 \mathrm{pmol} / \mathrm{L}$ (normal range $1.1-6.9 \mathrm{pmol} / \mathrm{L}$ ) were detected on admission and monitored. Thyroid function tests where within normal limits.

Tranexamic acid was administered with an initial working diagnosis being a retropharyngeal bleed, however, no airway compromise exhibited. Cardiothoracic assessment deemed that haemothoraces did not require invasive intervention, in view of their limited size.

\section{TREATMENT}

Critical care admission for observation was the initial management. A repeat FNE the following day showed bruising along the posterior pharyngeal wall; however, no pulsation, bulge or active bleeding was seen. The patient was stepped down to ward-level care 2 days later following improved neck movement, resolving ecchymosis and oropharyngeal swelling. Five days after admission, patient was discharged home on five further days of oral tranexamic acid (1 g orally, three times per day). 
Table 1 Summary of data obtained from 39 case reports of spontaneous parathyroid haemorrhage between 2001 and 2020

\begin{tabular}{|c|c|c|}
\hline \multicolumn{3}{|l|}{ Patient demographics } \\
\hline Age $($ mean $\pm S D)$ & $56.56 \pm 12.67$ & \\
\hline Gender & $\begin{array}{l}\text { Males } \\
\text { Females }\end{array}$ & $\begin{array}{l}12 \\
27\end{array}$ \\
\hline \multicolumn{3}{|l|}{ Clinical presentation and investigations } \\
\hline $\begin{array}{l}\text { Presenting symptoms } \\
\text { (39/39 cases reported) }\end{array}$ & $\begin{array}{l}\text { Pain } \\
\text { Ecchymosis } \\
\text { Neck swelling } \\
\text { Hoarseness } \\
\text { Dyspnoea } \\
\text { Dysphagia }\end{array}$ & $\begin{array}{l}92.3 \%(36 / 39) \\
52.3 \%(20 / 39) \\
61.5 \%(24 / 39) \\
25.6 \%(10 / 39) \\
18.0 \%(7 / 39) \\
46.2 \%(18 / 39)\end{array}$ \\
\hline $\begin{array}{l}\text { Time of onset (mean days } \pm S D \text { ) } \\
\text { (31/39 cases reported) }\end{array}$ & $12.19 \pm 26.41$ & \\
\hline $\begin{array}{l}\text { Serum calcium } \\
\text { (35 cases reported) }\end{array}$ & $\begin{array}{l}\text { Elevated } \\
\text { Normal }\end{array}$ & $\begin{array}{l}88.6 \%(31 / 35) \\
11.4 \%(4 / 35)\end{array}$ \\
\hline $\begin{array}{l}\text { Serum parathyroid hormone } \\
\text { ( } 32 \text { cases reported) }\end{array}$ & $\begin{array}{l}\text { Elevated } \\
\text { Normal }\end{array}$ & $\begin{array}{l}93.8 \%(30 / 32) \\
6.3 \%(2 / 32)\end{array}$ \\
\hline \multicolumn{3}{|l|}{ Management } \\
\hline $\begin{array}{l}\text { Management approach } \\
\text { (35/39 cases reported) }\end{array}$ & $\begin{array}{l}\text { Deferred surgery } \\
\text { Emergency surgery } \\
\text { Immediate surgery }\end{array}$ & $\begin{array}{l}19 / 35 \\
2 / 35 \\
14 / 35\end{array}$ \\
\hline $\begin{array}{l}\text { Operative timing (mean days } \pm S D \text { ) } \\
\text { ( } 28 / 39 \text { cases reported) }\end{array}$ & $55.36 \pm 66.67$ & \\
\hline $\begin{array}{l}\text { Histology } \\
\text { (38 cases reported) }\end{array}$ & $\begin{array}{l}\text { Adenoma } \\
\text { Hyperplasia } \\
\text { Carcinoma } \\
\text { Cyst }\end{array}$ & $\begin{array}{l}24 / 38 \\
2 / 38 \\
1 / 38 \\
1 / 38\end{array}$ \\
\hline
\end{tabular}

Below each criterion, the number of cases reporting the specified data is documented.

Anterior neck ultrasound (US) was performed urgently as an outpatient 7 days after discharge. A normal appearance of the thyroid gland was reported, with no cysts or nodules present. Repeated $\mathrm{Ca}^{2+}$ and PTH remained elevated, and the patient was referred for further endocrinology assessment.

Single-photon emission with computed tomography scans showed focal uptake inferior to the right lobe of the thyroid, in keeping with a solitary parathyroid adenoma (figure 3). Focused parathyroidectomy was performed successfully 5 months later, with a postoperative PTH of $3.3 \mathrm{pmol} / \mathrm{L}$ and $\mathrm{Ca}^{2+}$ of

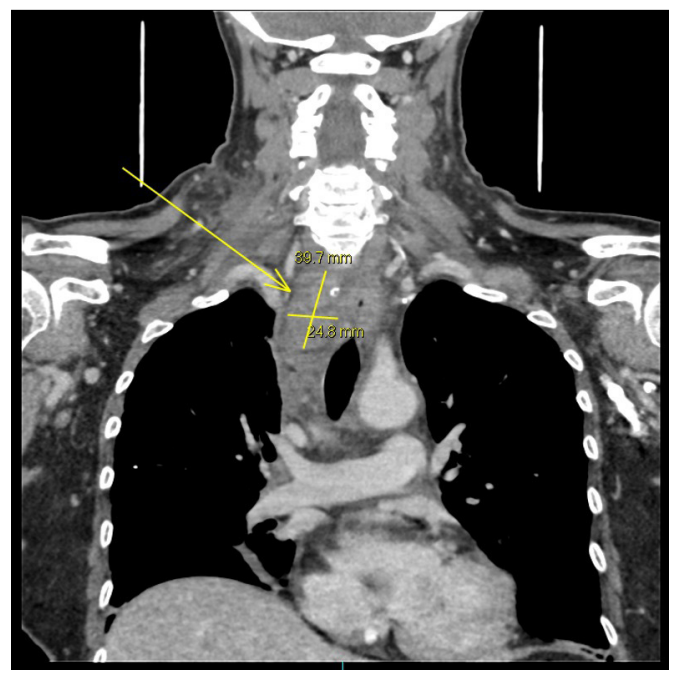

Figure 1 CT of the neck and chest (coronal view). Arrow pointing towards mediastinal haematoma.

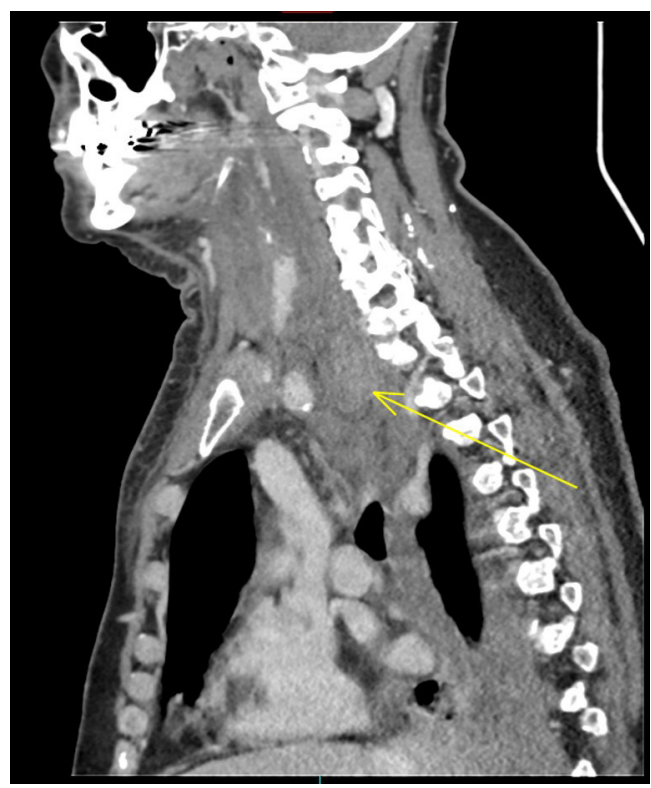

Figure 2 CT of the neck and chest (sagittal view). Arrow pointing towards mediastinal haematoma.

$2.30 \mathrm{mmol} / \mathrm{L}$. Histology confirmed a parathyroid oncocytic adenoma, with siderophages seen within and around the tumour.

\section{OUTCOME AND FOLLOW-UP}

Neither hoarseness nor symptoms of hypocalcemia were noted on follow-up, with normal $\mathrm{Ca}^{2+}$ and PTH levels 2 months after surgery. An outpatient appointment was arranged with the endocrinology team in 6 months' time for follow-up of her osteopenia detected in her lumbar spine.

\section{DISCUSSION}

Atraumatic cervical haematomas are potentially life-threatening occurrences, and diagnosis of the underlying cause can be challenging. Typical symptoms at presentation include neck swelling and ecchymosis, which should raise clinical suspicion. ${ }^{4}$ The primary differential includes a ruptured aneurysm or mediastinal mass, aortic dissection and descending necrotising mediastinitis, meriting urgent radiological imaging. ${ }^{467}$ Contrast-enhanced CT, MRI, US and nuclear medicine all assist in delineating the source of bleeding. ${ }^{4}$ However, these may fail to identify a parathyroid culprit obscured by acute haemorrhage, ${ }^{34}$ as seen in our case

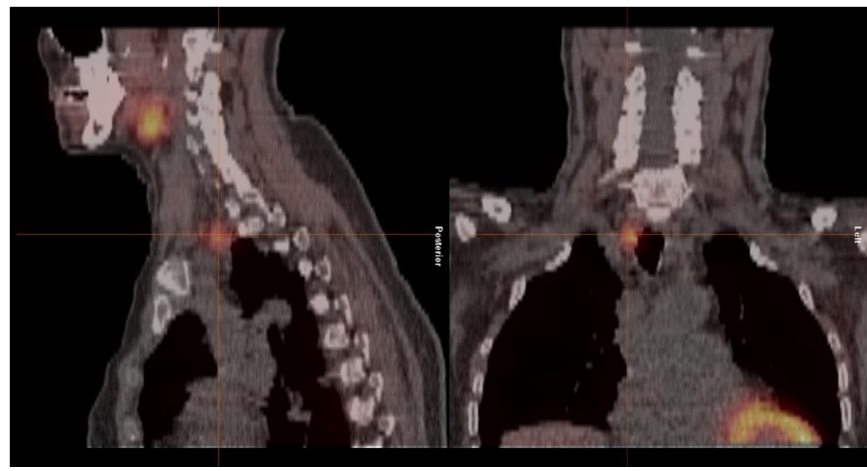

Figure 3 SPECT scans (parasagittal and coronal views). focal uptake in inferior to right lobe of thyroid. SPECT, single-photon emission with computed tomography. 
report. Shundo et al also remarked that MRI and US may falsely localise the source of bleeding to the thyroid gland. ${ }^{4}$

While an uncommon aetiology, parathyroid adenomas have been reported to instigate cervical haematomas. ${ }^{2}$ From a review of similar cases, it was commonly seen to occur in middle-aged women, in keeping with the increased incidence of PHPT in postmenopausal women. ${ }^{3}$ This is hypothesised to occur due to an imbalance of cell proliferation in relation to its blood supply, ${ }^{8-10}$ with a thin capsule allowing for easy rupture of a bleeding parathyroid tumour. ${ }^{8}$

In the acute setting where radiological testing may not reveal the underlying aetiology, raised serum $\mathrm{Ca}^{2+}$ is a strong diagnostic indicator of a parathyroid bleed. From our review of the current worldwide literature, only five case reports denied taking $\mathrm{Ca}^{2+}$ on work-up, ${ }^{3411-13}$ with $88.6 \%(31 / 35)$ showing an elevated $\mathrm{Ca}^{2+}$. 35 7-10 14-30

In the four cases with normal $\mathrm{Ca}^{2+},{ }^{60-32} \mathrm{PTH}$ was found to be elevated in one scenario. ${ }^{6}$ Shim et al hypothesised that such scenarios may represent either a non-functioning parathyroid adenoma or a necrotic lesion from the pressure effects of the haematoma. ${ }^{22}$

Simcic et al attempted to further delineate a diagnostic triad, ${ }^{33}$ considering a combination of neck swelling, ecchymosis and hypercalcaemia as pathognomonic for a haemorrhaging parathyroid tumour. ${ }^{33}$ While this is true for our reported case, the triad was witnessed in only $37.1 \%(13 / 35)$ of the cases with a $\mathrm{Ca}^{2+}$ result, due to a limited representation of swelling $(61.5 \%)$ and ecchymosis $(52.3 \%)$ in the reviewed reports. A summary of the initial symptoms on presentation can be found in table 1 .

No clear guidance exists for managing such presentations. Chaffanjon et al proposed a 3-month interval period prior to definitive surgery in the absence of VC involvement or respiratory distress, avoiding a potentially hostile environment. ${ }^{16}$ This allows for reabsorption of the haematoma, improved localisation of the lesion and preoperative planning. ${ }^{3} 1626$ Sixty per cent (19/35 of cases with documented surgical timing) adopted this conservative strategy, with surgery delayed by a minimum of 3 months. ${ }^{311}$ 14-17 22242527 30-32 Two cases required emergency interventions (cervical drainage, ${ }^{4}$ tracheostom ${ }^{21}$ ) to relieve compressive symptoms, with definitive surgery deferred to a later date. ${ }^{421}$ Curative surgery was performed within the same inpatient admission in 40\% (14/35),, 101316181923262829 with worsening compressive distress $(11 / 14)^{6} 10131618262829$ and deterioration in haemoglobin $(2 / 14)^{2327}$ being the chief concerns. Two authors acknowledged that immediate interventions resulted in difficult operative experiences due to large number of adhesions, necessitating hemithyroidectomies in both instances. ${ }^{37}$

Ulrich et al argued that patients with VC involvement should be operated within a month, minimising the risk of re-bleeding and recurrent laryngeal nerve injury secondary to tethering. ${ }^{27}$ From our review, VC immobility was described in six patients on initial FNE. ${ }^{3} 121632$ Four patients underwent surgery within 4 weeks, of initial presentation ${ }^{9162632}$ with VC paralysis persisting in two cases. ${ }^{2632} \mathrm{VC}$ paralysis was also seen to persist in a further case from the literature review, ${ }^{12}$ although timing of surgery was not documented.

Our case study and literature review highlight the importance of serum $\mathrm{Ca}^{2+}$ in spontaneous neck haemorrhage, with parathyroid adenoma being a possible culprit. In such scenarios, definitive operative management is best deferred in the absence of airway compromise or VC paresis, achieving better surgical outcomes when compared with immediate curative procedures. $^{216}$

\section{Patient's perspective}

The speed at which the swelling and bruising developed from out of the blue was concerning and I did not know what to make of it at first. When a relative working in the healthcare sector came over to examine me, she spotted blood at the back of my throat and that's what made me panic and fear the worst. Looking back to when I attended Accident \& Emergency, I was surprised that the extensive $\mathrm{X}$-ray imaging could not show what was causing the bleed. In the end, I am very grateful for the way they handled my care and escalated me to an intensive care unit. The spontaneity of the whole event still remains a bit of a mystery to me. While I still think about what could have triggered it, the medical team caring for me did say that bleeds from the parathyroid glands tend to happen without provocation. I am very pleased with the result of the surgery and that normality in my life has resumed!

\section{Learning points}

- Calcium profile should be ordered as part of initial investigations for atypical non-traumatic neck swelling/ suspected cervical haemorrhage.

- Radiological investigations may fail to identify parathyroid culprit if obscured by active bleeding.

- Combination of acute neck swelling, ecchymosis and hypercalcaemia should make the practitioner highly suspicious of parathyroid haemorrhage.

- Initial conservative approach is preferred with definitive surgical management deferred for a minimum of 3 months.

- Patients with respiratory distress, symptoms of compression and vocal cord involvement are candidates for emergency surgical management.

Contributors All authors were responsible for the care of the patient. MZ was responsible for writing up the case report and literature review, while RS and AP reviewed the final paper and obtained consent from the patient.

Funding This study was funded by Liverpool University Hospitals NHS Foundation Trust.

Competing interests None declared.

Patient consent for publication Obtained.

Provenance and peer review Not commissioned; externally peer reviewed.

\section{REFERENCES}

1 Novodvorsky P, Hussein Z, Arshad MF, et al. Two cases of spontaneous remission of primary hyperparathyroidism due to auto-infarction: different management and their outcomes. Endocrinol Diabetes Metab Case Rep 2019;2019. doi:10.1530/EDM-180136. [Epub ahead of print: 07 May 2019].

2 Capps RB. Multiple parathyroid tumors with massive mediastinal and subcutaneous hemorrhage. Am J Med Sci 1934;188:800-4

3 Tessler I, Adi M, Diment J, et al. Spontaneous neck hematoma secondary to parathyroid adenoma: a case series. Eur Arch Oto-rhino-/ 2020;11:1-8.

4 Shundo $Y$, Nogimura $H$, Kita Y, et al. Spontaneous parathyroid adenoma hemorrhage. Jpn J Thorac Cardiovasc Surg 2002;50:391-4.

5 Alfraidy D, Helmi H, Alamodi Alghamdi M, et al. Rare cause of acute neck hematoma. Clinical Case Reports 2019;3:1378-81.

6 Tonerini M, Orsitto E, Fratini L, et al. Cervical and mediastinal hematoma: presentation of an asymptomatic cervical parathyroid adenoma: case report and literature review. Emerg Radiol 2004;10:213-5.

7 Khan S, Choe CC, Shabaik A, et al. Parathyroid adenoma presenting with spontaneous cervical and anterior mediastinal hemorrhage: a case report. Medicine 2019:98:e14347

8 Shinomiya H, Otsuki N, Takahara S-I, et al. Parathyroid adenoma causing spontaneous cervical hematoma: two case reports. BMC Res Notes 2015;8:726. 
9 Ivkić B, Košec A, Vagić D, et al. Spontaneous massive extracapsular haemorrhage in a parathyroid carcinoma. Clin Endocrinol 2020;92:77-9.

10 Merante-Boschin I, Fassan M, Pelizzo MR, et al. Neck emergency due to parathyroid adenoma bleeding: a case report. J Med Case Rep 2009;3:7404.

11 Taniguchi I, Maeda T, Morimoto K, et al. Spontaneous retropharyngeal hematoma of a parathyroid cyst: report of a case. Surg Today 2003:33:354-7.

12 Terada T, Kawata R, Higashino M, et al. Sudden dysphonia due to spontaneous bleeding in secondary parathyroid hyperplasia. Arch Otolaryngol Head Neck Surg 2007:133:608-9.

13 Yoshimura N, Mukaida H, Mimura T, et al. A case of an acute cervicomediastinal hematoma secondary to the spontaneous rupture of a parathyroid adenoma. Ann Thorac Cardiovasc Surg 2014;20 Suppl:816-20.

14 Kihara M, Yokomise H, Yamauchi A, et al. Spontaneous rupture of a parathyroid adenoma presenting as a massive cervical hemorrhage: report of a case. Surg Today 2001:31:222-4.

15 Kozlow W, Demeure MJ, Welniak LM, et al. Acute extracapsular parathyroid hemorrhage: case report and review of the literature. Endocr Pract 2001:7:32-6.

16 Chaffanjon PCJ, Chavanis N, Chabre 0, et al. Extracapsular hematoma of the parathyroid glands. World J Surg 2003:27:14-17.

17 Maweja S, Sebag F, Hubbard J, et al. [Spontaneous cervical haematoma due to extracapsular haemorrhage of a parathyroid adenoma: a report of 2 cases]. Ann Chir 2003; 128:561-2.

18 Govindaraj S, Wasserman J, Rezaee R, et al. Parathyroid adenoma autoinfarction: a report of a case. Head Neck 2003:25:695-9.

19 Akimoto T, Saito O, Muto S, et al. A case of thoracic hemorrhage due to ectopic parathyroid hyperplasia with chronic renal failure. Am J Kidney Dis 2005;45:e109-14.

20 Devèze A, Sebag F, Pili S, et al. Parathyroid adenoma disclosed by a massive cervical hematoma. Otolaryngol Head Neck Surg 2006;134:710-2.
21 Nito T, Miyajima C, Kimura M, et al. Parathyroid adenoma causing spontaneous cervical hematoma: a case report. Acta Otolaryngol Supp/ 2007;127:160-3.

22 Shim WS, Kim IK, Yoo SD, et al. Non-Functional parathyroid adenoma presenting as a massive cervical hematoma: a case report. Clin Exp Otorhinolaryngol 2008;1:46.

23 Huang J, Soskos A, Murad S, et al. Spontaneous hemorrhage of a parathyroid adenoma into the mediastinum. Endocrine Practice 2012:18:e57-60.

24 Givens DJ, Hunt JP, Bentz BG. Uncommon presentations of parathyroid adenoma. Head Neck 2013:35:E265-8.

25 Sim I-W, Farrell S, Grodski S, et al. Parathyromatosis following spontaneous rupture of a parathyroid adenoma: natural history and the challenge of management. Intern Med J 2013:43:819-22.

26 Ilyicheva E. Spontaneous cervical-mediastinal hematoma caused by hemorrhage into parathyroid adenoma: a clinical case. Int I Surg Case Rep 2015;6:214-7.

27 Ulrich L, Knee G, Todd C. Spontaneous cervical haemorrhage of a parathyroid adenoma. Endocrinol Diabetes Metab Case Rep 2015:2015:150034.

28 Garrahy A, Hogan D, O'Neill JP, et al. Acute airway compromise due to parathyroid tumour apoplexy: an exceptionally rare and potentially life-threatening presentation. BMC Endocr Disord 2017;17:35.

29 Gorris MA, Guido MV, Rawla MS, et al. Parathyroid hemorrhage. J Emerg Med 2017; 52:e193-4.

30 An L, Ji T, Li L. Diffuse hematoma caused by spontaneous rupture of a parathyroid adenoma: a case report. Braz J Otorhinolaryngol 2017. doi:10.1016/j. bjorl.2017.06.006. [Epub ahead of print: 07 Jul 2017].

31 Nakajima J, Takamoto S, Tanaka M, et al. Parathyroid adenoma manifested by mediastinal hemorrhage: report of a case. Surg Today 2002;32:809-11.

32 Rehman HU, Markovski M, Khalifa A. Spontaneous cervical hematoma associated with parathyroid adenoma. Can Med Assoc J 2010;182:E632.

33 Simcic KJ, McDermott MT, Crawford GJ. Massive extracapsular hemorrhage from a parathyroid cyst. Arch Surg 1989;124:1347-50.

Copyright 2020 BMJ Publishing Group. All rights reserved. For permission to reuse any of this content visit

https://www.bmj.com/company/products-services/rights-and-licensing/permissions/

BMJ Case Report Fellows may re-use this article for personal use and teaching without any further permission.

Become a Fellow of BMJ Case Reports today and you can:

- Submit as many cases as you like

- Enjoy fast sympathetic peer review and rapid publication of accepted articles

- Access all the published articles

Re-use any of the published material for personal use and teaching without further permission

Customer Service

If you have any further queries about your subscription, please contact our customer services team on +44 (0) 2071111105 or via email at support@bmj.com.

Visit casereports.bmj.com for more articles like this and to become a Fellow 